\title{
Inhibition of nitric oxide and lipid accumulation by Sargassum sp. seaweeds and their antioxidant properties
}

\author{
SoHyeon $\mathrm{You}^{1 \neq}$, Miran Jang ${ }^{2 \ddagger}$, Gun-Hee Kim ${ }^{1 *}$ \\ ${ }^{1}$ Plant Resources Research Institute, Duksung Women's University, Seoul 01369, Korea \\ ${ }^{2}$ Department of Food and Life Science, Inje University, Gimhae 50834, Korea
}

\section{모자반 19종의 항산화, 지질 축적 및 NO 생성억제 효능

\author{
${ }^{1}$ 덕성여자대학교 식물자원연구소, ${ }^{2}$ 인제대학교 식품생명과학부
} \\ 유소현 ${ }^{1}$ - 장미란 ${ }^{2 \ddagger}$. 김건희 ${ }^{1 *}$}

\begin{abstract}
Recently, the use of seaweed has attracted significant attention and has resulted in several seaweed-based studies for developing health-promoting foods. Sargassum sp. has been consumed as a part of the diet for centuries, especially in Asian countries, and has been reported to exhibit diverse biological effects, such as antioxidant, anti-obesity, and anti-inflammation effects. The present study involved the evaluation of the total phenolics content and in vitro antioxidant activities of seaweed using 2,2'-diphenyl-1-picrylhydrazyl (DPPH) and 2,2'-azinobis-(3-ethylbenzthiazoline6-sulfonic acid) (ABTS) assays. Moreover, the inhibitory effect of lipid accumulation during the production of 3T3-L1 adipocytes and nitric oxide (NO) in RAW264.7 macrophages were investigated. The results revealed that Sargassum siliquastrum contained the highest total phenolics content (36.67 mg GAE/g of extract) and exhibited the highest antioxidant activity among the 19 Sargassum sp. seaweeds. In terms of the anti-adipogenic activity, the Sargassum nipponium and Sargassum siliquastrum extracts significantly inhibited lipid accumulation (up to 63\%) compared to that of the control in 3T3-L1 cells. Additionally, the Sargassum sagamianum extract inhibited NO production (up to $85 \%$ ) in lipopolysaccharide-induced RAW264.7 cells. Our results provide evidence that Sargassum sp. could be useful for the development of healthy functional foods.
\end{abstract}

Key words : Sargassum sp., polyphenol, antioxidative activity, anti-obesity, anti-inflammation

\section{서 론}

모든 세포는 생명 유지를 위한 에너지 생성과정에서 산소 를 필요로 하는데, 에너지 대사에 사용되는 산소 중 일부는 부산물인 활성산소(reactive oxygen species, ROS)로 전환이 된다(Kim 등, 2016). ROS에는 superoxide anion, hydrogen peroxide 및 hydroxyl radical 등이 있으며(Lee 등, 2011), 이
들은 세포 내 신호 및 면역반응에 기여하지만 과도하게 생성 될 경우, 세포 내 소기관들을 공격하여 질병을 일으킬 수 있 다(Cho 등, 2008). 생체는 이러한 활성산소종의 생성을 차단 및 감소시키기 위한 항산화 시스템을 가지고 있는데, 정상적 인 상태에서는 생체의 항산화 시스템에 의해 산화작용에 대 한 방어 작용을 한다. 그러나 환경 및 질병 등에 의해 산화 및 항산화 작용의 평형이 깨지게 되면, 산화적 스트레스가 발

\footnotetext{
*Corresponding author. E-mail : ghkim@duksung.ac.kr, Phone : +82-2-901-8496, Fax : +82-2-901-8661

${ }^{\ddagger}$ These authors contributed equally to this work.

Received 12 November 2020; Revised 10 December 2020; Accepted 21 January 2021.

Copyright (c) The Korean Society of Food Preservation.

This is an Open Access article distributed under the terms of the Creative Commons Attribution Non-Commercial License (http://creativecommons.org/licenses/by-nc/4.0) which permits unrestricted non-commercial use, distribution, and reproduction in any medium, provided the original work is properly cited.
} 
생하게 되고, 이것은 세포내 지질, 단백질, 또는 DNA 손상을 일으켜 정상적인 신체 기능을 억제하게 된다(Jo 등, 2010; Koh 등, 2008).

한편, 경제의 발전 및 삶의 질 향상으로 비만은 전세계적 인 사회적 문제로 간주되고 있다. 비만은 체내 지방이 과도하 게 축적된 상태를 의미하며, 고혈압, 당뇨, 고지혈증 및 대사 증후군을 일으키는 주된 원인이다(Lee 등, 2014). 최근 지방 세포 내 생성된 ROS가 지방세포의 분화와 밀접한 연관을 갖 는다고 보고되었다(Park 등, 2013). 특히 지방세포가 비대해 질 경우, 정상 세포에 비하여 많은 유리지방산을 생성하며, 증가한 유리지방산은 활성산소종의 생성을 촉진시켜 염증, 암 및 심혈관계 질환 등의 질병을 유발하게 된다(Choi 등, 2013; Lee 등, 2011).

해양은 지구 표면적의 $70 \%$ 를 차지하고 있으며, 지구 생물 종의 $80 \%$ 이상이 서식하고 있다. 또한, 해양에는 막대한 자 원을 보유하고 있다고 보고되어, 육상 생물자원을 대체할 중 요한 식량자원으로 주목을 받고 있다(Kim 등, 2013). 우리나 라는 삼면이 바다로 둘러싸여 있어 다양한 해양생물을 획득 하기에 용이하며, 특히 예로부터 김, 미역, 다시마 등과 같은 해조류를 다양한 방법으로 섭취해 왔다(Kim 등, 2015a). 또 한 해양식물은 육상식물과 다른 대사과정 및 생육환경으로 인하여 특이적으로 생리활성을 나타내는 유효성분들을 다량 함유하고 있어 식 - 의약품 기능성 연구로 가치가 높은 소재 로 평가된다(Kim 등, 2013; Kim 등, 2016; Kwon과 Youn, 2017). 그 중, 모자반(Sargassum)은 모자반목(Fucales) 모자 반과(Sargassaceae)에 속하는 갈조류의 일종으로 우리나라의 동남해안에서 쉽게 채취되며, 400 여 개의 다양한 종이 존재 하는 것으로 알려져 있다(Oak과 Lee, 2005; Yeon 등, 2010). 예로부터 모자반은 한국과 중국에서 약용 및 식용으로 이용 되어 왔으며, 다양한 생리활성 물질을 함유하고 있는 것으로 기록되었다(Choi 등, 2019; Koo 등, 2001). 따라서 본 연구에 서는 모자반의 건강기능성 소재로서의 가능성을 평가하기 위 하여 19 종의 모자반 에탄올 추출물이 함유하는 페놀 함량을 확인하였으며, 자유라디칼 소거능, 지질축적억제능 및 세포 내 $\mathrm{NO}$ 생성억제능을 평가하였다.

\section{재료 및 방법}

\section{시약 및 기기}

페놀 함량 및 라디칼 소거능 측정에 사용된 Folin-Ciocalteu reagent, 1-1-diphenyl-2-picrylhydrazyl(DPPH), 2,2'-azinobisbis(3-ethylbenzothiazoline-6-sulfonic acid)(ABTS) 시약은 Sigma-Aldrich Chemical Co.(St. Louis, MO, USA)에서 구 입하여 사용하였다. 세포 배양에 사용한 Dulbecco's modified
Eagle's medium(DMEM), phosphate buffered saline(PBS), fetal bovine serum(FBS), $0.25 \%$ trypsin-EDTA 및 penicillin/ streptomycin은 WellGENE(Daegu, Korea)에서 구입하였다. Insulin, 3-isobutyl-1-methylxanthine(IBMX), dexamethasone (DEX), Oil Red O, dimethyl sulfoxide(DMSO)는 SigmaAldrich Co.(USA)에서 구입하여 사용하였다.

\section{실험재료}

본 연구에서 사용된 모자반 추출물은 제주생물종다양성연 구소에서 제공받았으며, 갈래잎모자반(Sargassum pinnatifidum Harvey), 경단구슬모자반(Sargassum muticum (Yendo) Fensholt), 고사리모자반(Sargassum filicinum Harvey), 괭생이모자반 (Sargassum horneri (Turner) C. Agardh), 꼬마모자반(Sargassum nipponium Yendo), 꽈배기모자반(Sargassum siliquastrum (Mertens ex Turner) C. Agardh), 큰열매모자반(Sargassum macrocarpum C. Agardh), 비틀대모자반(Sargassum sagamianum Yendo), 쌍발이모자반(Sargassum patens C. Agardh), 알쏭이 모자반(Sargassum confusum C. Agardh), 외톨개모자반(Myagropsis myagroides (Martens ex Turner) Fensholt), 잔가시모자반 (Sargassum micracanthum (Kützing) Enflicher), 지충이 (Sargassum thunbergii (Mertens es Roth) Kuntze), 짝잎모자 반(Sargassum hemiphyllum (Turner) C. Agardh), 큰잎모자반 (Sargassum coreanum J. Agardh), 큰잎알쏭이모자반(Sargassum pallidum (Turner) C. Agardh), 큰톱니모자반(Sargassum giganteifolium Yamada), 톱니모자반(Sargassum serratifolium C. Agardh), 톳(Sargassum fusiformis (Harvey) Setchell)을 포함한 총 19 개의 추출물은 DMSO에 stock하여 증류수로 농 도에 맞게 희석하여 실험에 사용하였다.

\section{총페놀 함량 측정}

총페놀 함량 측정은 Folin-Denis 방법(Folin과 Denis, 1912) 을 이용하여 측정하였다. 즉, 모자반 추출물 $70 \mu \mathrm{L}$ 에 $2 \mathrm{~N}$ Folin-Ciocalteu 용액 $70 \mu \mathrm{L}$ 를 가하여 3 분간 반응시킨 후 $2 \%$ $\mathrm{Na}_{2} \mathrm{CO}_{3} 70 \mu \mathrm{L}$ 를 첨가하여 1시간 상온에 방치 후 spectrophotometer(SpectraMax M2, Molecular Decives, San Jose, $\mathrm{CA}, \mathrm{USA}$ )를 이용하여 $760 \mathrm{~nm}$ 에서 흡광도를 측정하였다. 표 준물질로는 gallic acid를 이용하였으며, 시료와 동일한 방법 으로 분석하여 작성한 표준곡선으로부터 총페놀 함량을 산출 하였다.

\section{$\mathrm{DPPH}$ 라디칼 소거능 측정}

모자반 추출물의 DPPH 라디칼 소거 활성은 Ramos 등 (2003)의 방법을 본 시료에 맞게 변형하여 측정하였다. 각 추 출물과 $0.2 \mathrm{mM} \mathrm{DPPH}$ 용액을 30 분 동안 반응시킨 후 
spectrophotometer를 이용하여 $515 \mathrm{~nm}$ 에서 흡광도를 측정하 였다. DPPH 라디칼 소거 활성은 아래 식을 이용하여 계산하 였다.

DPPH radical scavenging acitivty $(\%)=$

$$
(\mathrm{A}-\mathrm{B}) / \mathrm{A} \times 100
$$
A: absorbance of the blank
B: absorbance of the sample

\section{ABTS 라디칼 소거능 측정}

ABTS 라디칼 소거 활성은 Re 등(1999)의 방법을 본 시료 에 맞게 변형하여 측정하였다. ABTS stock 용액 제조를 위하 여 $7.4 \mathrm{mM} \mathrm{ABTS}$ 와 $2.6 \mathrm{mM}$ potassium persulfate를 혼합하 여 암소에서 24시간 동안 방치하였다. 이후 $735 \mathrm{~nm}$ 에서 흡 광도가 0.7-0.8이 되도록 ABTS stock 용액을 phosphate buffer saline(PBS, pH 7.4)로 희석하였다. 희석한 ABTS reagent $150 \mu \mathrm{L}$ 에 추출물을 $50 \mu \mathrm{L}$ 가하여 5 분간 방치하였으 며, $735 \mathrm{~nm}$ 에서 흡광도를 측정하였다. ABTS 라디칼 소거 활 성은 아래의 식을 이용하여 계산하였다.

ABTS radical scavenging activity $(\%)=$

$$
(\mathrm{A}-\mathrm{B}) / \mathrm{A} \times 100
$$
A: absorbance of the blank
B: absorbance of the sample

\section{세포 배양}

실험에 사용한 마우스 유래 macrophage 세포주인 RAW 264.7 및 3T3-L1 preadipocyte는 한국세포주은행(KCLB, Seoul, Korea)에서 분양받아 사용하였다. RAW 264.7 세포 의 배양은 $10 \% \mathrm{FBS}$ 와 $1 \%$ penicillin/streptomycin이 첨가된 $\mathrm{DMEM}$ 배지를 사용하였으며, $37^{\circ} \mathrm{C}, 5 \% \mathrm{CO}_{2}$ incubator (MCO-15AC, SANYO, Osaka, Japan)에서 배양하였다. 3T3-L1 preadipocyte는 $10 \% \mathrm{FBS}$ 와 $1 \%$ penicillin/streptomycin이 함 유된 DMEM을 이용하여 $37^{\circ} \mathrm{C}, 5 \% \mathrm{CO}_{2}$ incubator에서 배양 하였으며, 세포는 2일마다 계대 배양하였다. 3T3-L1 preadipocyte의 분화를 유도하기 위하여 세포가 $100 \%$

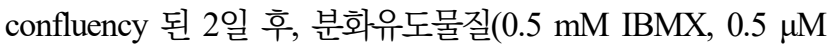
$\mathrm{DEX}, 10 \mu \mathrm{g} / \mathrm{mL}$ Insuline, $\mathrm{MDI}$ )이 함유된 배지와 추출물을 2 일간 교체하며 세포를 배양하였다. 분화유도 후, 추출물과 $10 \mu \mathrm{g} / \mathrm{mL}$ 의 insulin이 포함된 배지로 교환하여 배양하였다.

\section{세포독성 시험}

모자반 추출물의 세포 독성 실험은 MTT assay를 이용하 여 측정하였다. MTT 용액은 3-(4,5-dimethylthiazol-2-yl)-2,5- diphenyltetrazolium bromide을 $5 \mathrm{mg} / \mathrm{mL}$ 의 농도로 PBS에 녹 여 사용하였다. 세포를 $1.0 \times 10^{5}$ cells/well의 농도로 96-well plate에 분주하고 24 시간 동안 배양한 후, 추출물을 처리하여 24 시간 동안 배양하였다. 배양 후, MTT 용액 $20 \mu \mathrm{L}$ 를 처리 한 후 $5 \% \mathrm{CO}_{2}$ incubator에서 4 시간 배양시켰으며, 배지를 제 거하고 남은 formazan을 DMSO로 용해시켜 $570 \mathrm{~nm}$ 에서 흡 광도를 측정하였다. 세포 생존율은 대조군 대비 백분율로 나 타내었다.

\section{Oil Red 0 염색}

지방세포 분화 과정 중 형성된 지질의 축적량은 Oil Red $\mathrm{O}$ 염색법을 이용하여 측정하였다. 8 일 동안 분화한 세포의 배지를 제거한 뒤, PBS로 세포를 2회 세척한 다음, $10 \%$ formalin 용액으로 상온에서 30 분간 고정하였다. 고정된 세 포를 PBS로 세척한 뒤, Oil Red O 용액을 각 well에 첨가하 여 실온에서 1 시간 동안 염색하였다. 염색된 세포의 lipid droplet의 함량을 측정하기 위하여 세포를 PBS로 세척한 다 음 염색된 Oil Red O를 100\% isopropyl alcohol을 이용하여 용해한 후 $510 \mathrm{~nm}$ 에서 흡광도를 측정하였다. 지질 축적량은 정상 대조군 대비 백분율로 나타내었다.

\section{RAW 264.7 cell을 이용한 NO 생성 저해 능력 측정}

LPS로 유도된 RAW 264.7 세포에서 모자반 추출물의 NO 생성억제능을 측정하기 위하여 Griess assay를 이용하여 세 포 배양액의 NO 생성량을 측정하였다. RAW 264.7 세포를 $1 \times 10^{5} \mathrm{cell} / \mathrm{well}$ 의 농도로 96 well plate에 분주하여 24시간 동 안 $37^{\circ} \mathrm{C}, 5 \% \mathrm{CO}_{2}$ incubator에서 배양하였다. 배양한 세포에 추출물을 처리하여 6시간 동안 배양한 뒤, LPS를 $1 \mu \mathrm{g} / \mathrm{mL}$ 첨 가하여 $24 \mathrm{~h}$ 배양하였다. 96-well plate에 세포배양 상등액 $100 \mu \mathrm{L}$ 와 동량의 Griess 시약을 혼합하여 상온에서 10 분 동 안 반응시킨 후 $540 \mathrm{~nm}$ 에서 흡광도를 측정하였다. $\mathrm{NO}$ 생성 량은 정상 대조군 대비 백분율로 나타내었다.

\section{통계처리}

모든 실험 결과는 3 회 반복 측정하였으며, 평균값과 표준 편차 $(\operatorname{mean} \pm \mathrm{SD}$ )로 나타내었다. 통계처리는 SPSS 18.0(SPSS Inc., Chicago, IL, USA)을 이용하여 one-way ANOVA(analysis of variation)를 실시한 후, $\mathrm{p}<0.05$ 수준에서 Duncan's multiple range test로 사후 검정하여 실험에서의 유의성을 검 증하였다.

\section{결과 및 고찰}

\section{총페놀 함량}

식품 속에는 생리활성을 나타내는 phytochemical이 있으 
며, 그 중 tannin, procyanidin, flavonoid, phenolic acid와 같 은 페놀 화합물은 식물 속에 가장 많이 함유되어 있는 2차 대사산물이다(Choi 등, 2010; Park 등, 2015). 이들의 방향족 고리 구조에 붙어있는 다수의 phenolic hydroxyl기는 단백질, 효소단백질 및 기타 거대분자들과 쉽게 결합하는 성질을 가 지고 있어 항균, 항산화 및 항염 효과가 뛰어난 것으로 보고 되었다(Cho 등, 2018; Kim 등, 2012). 식물의 다양한 생리활 성은 식물이 함유하고 있는 페놀성 화합물의 함량과 비례적 으로 증가하는 경향이 있다고 보고되었다. 따라서 식물이 함 유하고 있는 페놀 함량은 천연물이 나타내는 항산화 활성을 평가하는 기초자료로 활용이 될 수 있다(Kim 등, 2013).

모자반 19종의 총폴리페놀 화합물 함량은 Fig. 1에 제시하 였다. 총페놀 함량을 분석 결과, $1.34-36.67 \mathrm{mg} / \mathrm{g}$ extract의 함량 범위로 나타났으며, 꽈배기모자반(36.67 mg/g extract), 고사리모자반 $(26.87 \mathrm{mg} / \mathrm{g}$ extract), 큰열매모자반 $(22.31 \mathrm{mg} / \mathrm{g}$ extract) 순으로 높은 함량을 나타냈다. 반면, 가장 낮은 페놀 함량을 나타낸 모자반은 쌍발이모자반 $(1.34 \mathrm{mg} / \mathrm{g}$ extract)으 로 나타났다. Son 등(2016)은 해조류를 대상으로 페놀 함량 을 분석하였으며, 꽈배기 모자반이 실험에 사용된 모자반 중 가장 높은 함량을 보여 본 연구와 유사한 결과를 나타냈다. 한편, Cho 등(2007)은 꽈배기 모자반 에탄올 분획 추출물의 페놀 함량이 $127.3 \mathrm{mg} / \mathrm{g}$ 으로 본 연구와 비교했을 때 상당히 높은 페놀 함량을 나타냈는데, 이러한 결과는 해조류의 자생 지역, 시기 및 추출 방법의 차이 때문인 것으로 사료된다.

해조류는 녹조류(Chlorophyceae), 갈조류(Phaeophyceae) 및 홍조류(Rhodophyceae)로 분류가 되는데, 그중 모자반이 속한 갈조류가 녹조류 및 홍조류에 비하여 우수한 생리활성

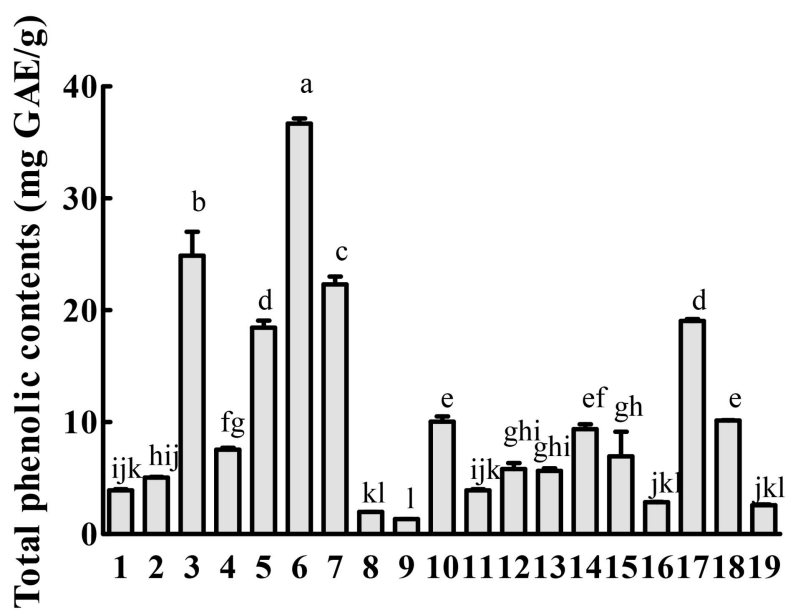

Fig. 1. Total phenolics contents.

All values are expressed as the mean \pm SD of tiplicate analyses. Different superscript letters on the bars show significant differences among groups $(\mathrm{p}<0.05)$.
을 나타낸다고 보고되었다(Kim 등, 2013; Oh와 Lee, 2015). 갈조류에는 플로로탄닌(phlorotannin)을 다량 함유하고 있는 것으로 알려져 있다. 플로로탄닌은 플로로글루시놀[phloroglucinol(1,3,5-trihydroxybenzene)]을 단량체로 구성된 폴리 페놀계 화합물로, 항산화능, 혈압강하, 콜레스테롤 저하, 간 보호, 항바이러스 및 항박테리아, 항암, 항염 등의 다양한 생 리활성을 나타낸다고 보고되었다(Lee 등, 2020). 본 연구에 서는 19종 모자반의 총페놀 함량을 확인하였으며, 상기 실험 결과를 바탕으로 각 모자반의 라디칼 소거능, 지질축적억제 능 및 $\mathrm{NO}$ 생성억제능을 평가하였다.

\section{$\mathrm{DPPH}$ 및 $\mathrm{ABTS}$ 라디칼 소거능}

19 종의 모자반 추출물의 항산화 활성을 확인하기 위하여 $\mathrm{DPPH}$ 및 $\mathrm{ABTS}$ 라디칼 소거능을 측정하였다. $\mathrm{DPPH}$ 는 보라 색을 띄는 비교적 안정한 free radical로, 항산화 작용이 뛰어 난 물질들에 의해 환원되어 노란빛으로 탈색이 되는 특성을 가 지고 있다. 따라서 $\mathrm{DPPH}$ 의 보랏빛이 항산화 물질에 의해 탈색 되는 정도에 따라 물질의 항산화능을 확인할 수 있다(Kwak과 Lee, 2014). ABTS 라디칼 소거능은 potassium persulfate와 $\mathrm{ABTS}$ 가 반응하여 생성된 양이온 라디칼이 항산화 활성을 가진 물질에 의해 소거되어 본래의 청록색이 탈색되는 원리 를 이용하여 항산화력을 측정하는 방법이다(Cho 등, 2012).

각 모자반 추출물은 $1 \mathrm{mg} / \mathrm{mL}$ 의 농도로 희석하여 측정하 였으며, 결과는 Fig. 2에 제시하였다. 모자반 19종의 DPPH 라디칼 소거능을 확인한 결과, 꽈배기모자반(73.10\%), 큰열 매모자반(71.01\%), 큰톱니모자반(66.91\%) 순으로 높게 나타 났다. ABTS 라디칼 소거능을 확인한 결과에서는 꽈배기모자 반(88.75\%), 큰열매모자반(84.41\%), 고사리모자반(74.60\%) 순으로 높게 나타났다.

기존에 $\mathrm{DPPH}$ 및 $\mathrm{ABTS}$ 라디칼 소거능은 페놀 화합물 함 량과 밀접한 관계가 있다는 연구가 다수 보고되었다(Boo 등, 2009; Jung 등, 2017). Kwak과 Lee(2014)는 식용 해조류 5종 을 이용하여 항산화 활성을 평가하였으며, 해조류 추출물에 함유되어 있는 총페놀 함량에 비례하여 라디칼을 효과적으로 제거하는 결과를 나타내었다. 19종의 모자반 추출물의 총페 놀 함량과 라디칼 소거능의 상관관계를 분석한 결과(Table 1), 페놀 화합물의 함량이 증가할수록 DPPH 및 ABTS 라디 칼 소거능이 증가하는 경향을 보여 높은 정의 상관관계 $\left(\mathrm{r}^{2}=\right.$ $\left.0.808, \mathrm{p}<0.01 ; \mathrm{r}^{2}=0.883, \mathrm{p}<0.01\right)$ 를 나타내었으며, 기존 연구 결과와 일치하는 결과를 보였다. 특히, 가장 높은 페놀 함량 을 나타낸 꽈배기모자반 추출물에서 가장 높은 라디칼 소거 활성을 나타냈는데, 이러한 결과는 Cho 등(2007)의 37종의 해조류 추출물 중 꽈배기모자반이 가장 높은 항산화 활성을 나타냈다는 기존 연구결과에서도 확인할 수 있다. 이와 같이 
(A)

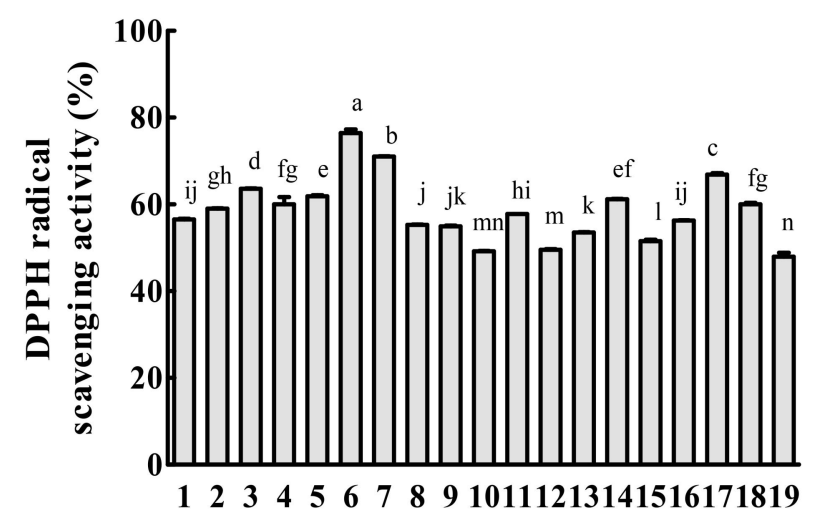

(B)

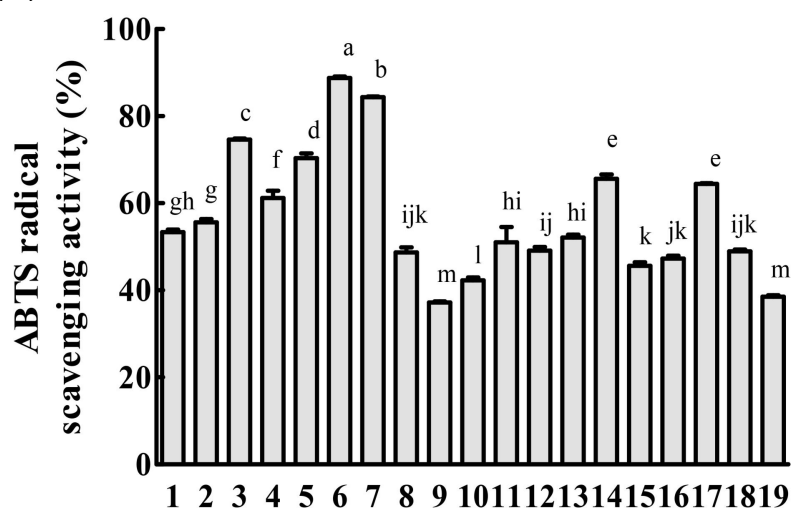

Fig. 2. Antioxidant activities of 19 Sargassum sp.

(A), DPPH radical scavenging activity; (B), ABTS radical scavenging activity.

All values are expressed as the mean $\pm \mathrm{SD}$ of tiplicate analyses. Different superscript letters on the bars show significant differences among groups $(\mathrm{p}<0.05)$.
우수한 꽈배기 모자반의 항산화 활성은 추출물이 함유하고 있는 페놀성 물질에 기인한 것으로 사료된다.

\section{세포생존율}

19종의 모자반 추출물이 3T3-L1 및 RAW264.7 세포의 생 존에 미치는 영향을 확인하기 위하여 MTT assay를 수행하였 으며, 결과는 Fig. $3 \mathrm{~A}$ 와 Fig. $4 \mathrm{~A}$ 에 제시하였다. 모자반 추출 물을 $100 \mu \mathrm{g} / \mathrm{mL}$ 농도로 3T3-L1 및 RAW264.7 세포에 처리 한 결과, 무처리군에 비하여 세포 생존율은 유의적인 차이를 보이지 않았다 $(\mathrm{p}<0.05)$.

\section{T3-L1 지방세포 분화 및 지방생성억제 효과}

지방전구세포인 3T3-L1은 in vitro에서 분화유도물질을 첨가하였을 때 지방세포로 전환되며, 세포내 지방을 축적 (adipogenesis)한다. 지방세포로의 분화가 유도되는 동안 CCAAT/enhancer-binding proteins(C/EBP) family와 peroxisome proliferator-activated receptor $\gamma(\mathrm{PPAR} \gamma)$ 와 같은 전사인 자들이 활성화되는데, 이들은 지방생성 조절 인자들의 상호 작용을 유도함으로써 지방세포 분화를 유도하는 것으로 알려 져 있다(Oh와 Lee, 2015; Park 등, 2014). 19종의 모자반 추 출물이 3T3-L1 preadipocyte의 지방구 형성에 미치는 영향을 확인하기 위하여 지방전구세포의 분화를 유도하였다. 그 후, lipid droplet만을 특이적으로 염색시키는 Oil red O 염색법을 통하여 지방 세포로의 분화억제 효과를 확인하였으며, 결과 는 Fig. 3B에 나타내었다. 모자반 추출물 $100 \mu \mathrm{g} / \mathrm{mL}$ 농도에서 꽈배기 모자반이 $(63.60 \%)$ 가장 효과적으로 지방 축적을 억제 하였으며, 꼬마모자반(63.42\%) 그리고 고사리모자반(59.28\%) 순으로 높은 지방 축적억제효과를 보였고, 그 이외에는 $50 \%$ 이하의 효과를 보였다.

Table 1. Correlation coefficients among total phenolics content, DPPH and ABTS radical scavenging activities as well as lipid and NO inhibition

\begin{tabular}{cccccc}
\hline \multirow{2}{*}{ Factor } & \multicolumn{5}{c}{ Correlation coefficient } \\
\cline { 2 - 5 } & $\mathrm{TPC}^{1)}$ & $\mathrm{DPPH}^{2)}$ & ABTS $^{3)}$ & Lipid inhibition & NO inhibition \\
\hline TPC & 1 & & & & \\
DPPH & $0.808^{* * 4}$ & 1 & & & \\
ABTS & $0.883^{* *}$ & $0.914^{* *}$ & 1 & 1 & 1 \\
Lipid inhibition & 0.362 & 0.273 & 0.384 & 0.013 & 1 \\
NO inhibition & 0.384 & 0.439 & $0.506^{*}$ & & \\
\hline
\end{tabular}

${ }^{1)}$ Total phenolics contents.

${ }^{2)} \mathrm{DPPH}$ radical scavenging activity.

${ }^{3)}$ ABTS radical scavenging activity

${ }^{4)}$ Significant difference at $\mathrm{p}<0.05,{ }^{* * *}$ Significant difference at $\mathrm{p}<0.01$ 
(A)

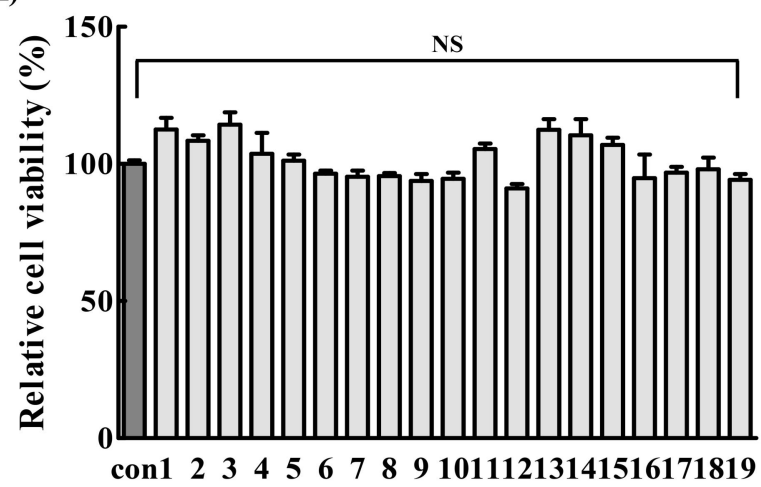

(B)

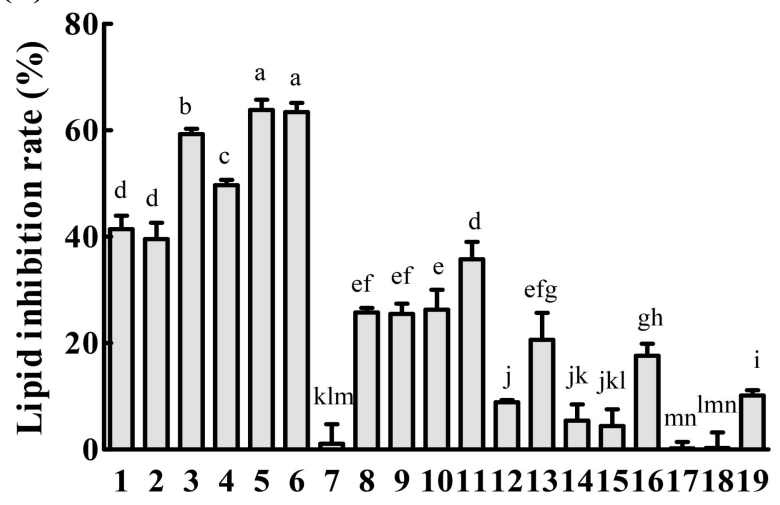

Fig 3. Inhibitory effects of Sarggasum sp. on lipid accumulation in 3T3-L during adipogenesis.

(A), viability of 3T3-L1 cells treated with Sargassum. sp.; (B), inhibition of lipid accumulation of Sargassum. sp. in 3T3-L1 adipocyte. All values are expressed as the mean \pm SD of tiplicate analyses. Different superscript letters on the bars show significant differences among groups $(\mathrm{p}<0.05)$.

con, control.

기존에 모자반류를 이용한 3T3-L1의 지방세포 분화억제 연구가 다수 보고되었다. Lee 등(2012)은 잔가시모자반 추출 물이 $100 \mu \mathrm{g} / \mathrm{mL}$ 의 농도에서 약 $49 \%$ 세포 내 지질축적을 억 제하였다고 보고하였으며, Kwon 등(2019)의 연구에서는 괭 생이모자반 추출물이 $250 \mu \mathrm{g} / \mathrm{mL}$ 의 농도부터 유의적으로 지 질축적을 억제하였다. Kong 등(2015)은 꽈배기모자반 추출 물이 $500 \mu \mathrm{g} / \mathrm{mL}$ 부터 유의적으로 지방세포의 분화와 세포 내 중성지질 축적을 억제한다고 보고하였다. 본 연구에 사용된 모자반 추출물은 대부분 $100 \mu \mathrm{g} / \mathrm{mL}$ 의 낮은 농도에서도 지질 축적억제 효과를 보여 기존의 연구들보다 우수한 효과를 나 타내었다. 또한, 기존 연구들에 사용된 모자반 추출물들은 공 통적으로 지방세포가 분화하는 데 관여하는 전사인자인 $\mathrm{PPAR} \gamma$ 및 $\mathrm{C} / \mathrm{EBP} \alpha$ 의 발현을 효과적으로 저해하였는데, 본 연구에서 나타낸 모자반 추출물의 지질 축적억제효과는 모자 반 추출물이 지방 생성 조절관련 인자들의 발현에 관여하기
(A)

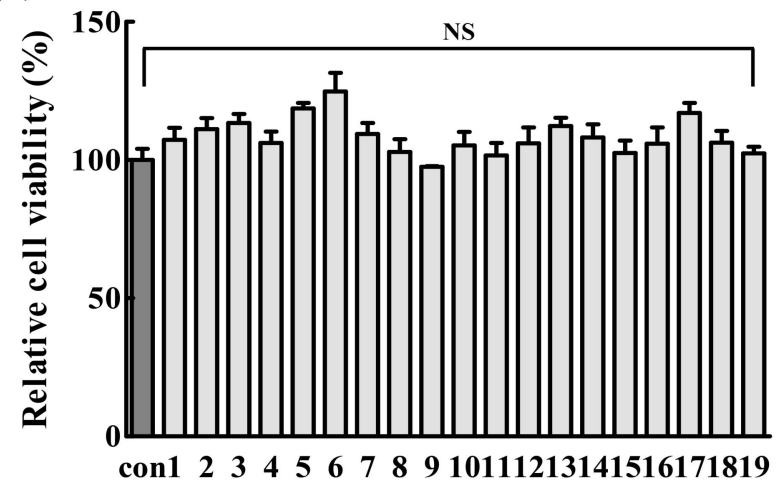

(B)

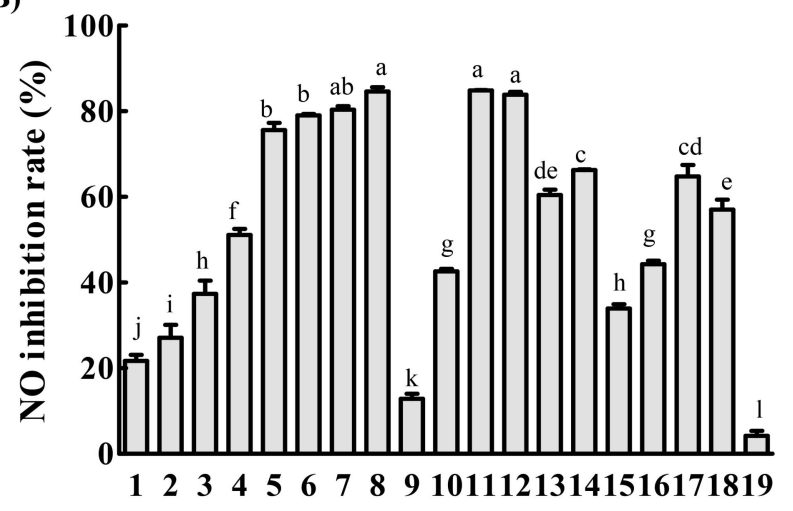

Fig 4. Inhibitory effects of Saggasum sp. on NO production in LPS-induced RAW 264.7.

(A), viability of RAW 264.7 cells treated with Sargassum. sp.; (B), inhibition of NO production of Sargassum. sp. in LPS-induced RAW 264.7 cells.

All values are expressed as the mean $\pm \mathrm{SD}$ of tiplicate analyses. Different superscript letters on the bars show significant differences among groups $(\mathrm{p}<0.05)$.

con, control.

때문인 것으로 판단된다.

전지방세포는 성숙된 지방세포로 분화가 되는 과정에서 지방합성을 필요로 하는 $\mathrm{NADPH}$ 를 생성하는데, $\mathrm{NADPH}$ 는 $\mathrm{NADPH}$ 산화효소(NADPH oxidase, NOX)와 같은 oxidant enzyme에 의해 활성산소종(reactive oxygen species, ROS)을 생성하여 산화 스트레스를 유발한다(Lee 등, 2012; Yoon 등, 2012). 본 연구에서 모자반류가 함유하고 있는 총 폴리페놀 의 함량과 지질축적억제 효과는 직접적인 상관관계가 나타나 지 않았지만(Table 1), 폴리페놀이 지방세포 분화 과정에서 생성되는 $\mathrm{ROS}$ 를 소거하는 효과를 기대해 볼 수 있을 것으로 사료된다.

\section{Nitric oxide(NO) 생성억제능}

지방 세포 내 과도하게 생성된 활성산소종은 지방전구세 포의 분화를 촉진시키거나 지방세포 주변에 위치한 macro- 
phage를 자극하여 다른 활성산소종을 생성함으로 비만의 주 요 원인으로 작용한다(Choi와 Kim, 2014). Nitric oxide(NO) 는 체내의 염증 및 면역과 밀접한 관련이 있는 반응성이 높은 자유라디칼로서 대식세포에서 주로 생성되며, 생체 내 염증 반응, 신경독성, 신호전달 및 체내방어 기능에 중요한 부분을 차지한다고 알려져 있다(Lee 등, 2006). NO는 매우 불안정한 화합물로서 염증 상태이거나 세균에 의해 방출된 내독소에 의해 NO 합성 효소인 inducible nitric oxide synthase(iNOS) 가 활성화되어 대량의 NO가 생성된다(Cheon 등, 2017; Lee 등, 2016). $\mathrm{NO}$ 는 분자상의 산소가 활성산소종으로 변하여 다 른 염증성 질환이나 자가 면역질환, 유전자 변이, 신경 및 조 직의 손상을 일으킬 수 있다. 따라서 과도한 $\mathrm{NO}$ 의 생성억제 는 질병 예방을 위해 중요하다(Choi 등, 2020).

최근 과도한 영양소 및 대사물질의 공급이 염증 반응을 일 으킨다는 'meta-inflammation'이라는 용어가 사용되면서, 비 만과 만성 염증과의 밀접한 관계에 대한 관심이 증가하고 있 다(Park 등, 2014). 염증상태는 지방조직 내에서 TNF- $\alpha$, $\mathrm{MCP}-1$ 및 NO와 같은 염증매개체를 분비함으로써 면역세포 들과의 상호작용에 의해 심각한 대사성 질환(제 2 형 당뇨 및 심혈관계 질환) 및 합병증을 유발하는 것으로 알려져 있다. 따라서 비만과 염증, 지방조직과 면역체계, 지방세포와 면역 세포와 관련된 연구가 필요하다.

19 종의 모자반 추출물의 항염증 활성을 확인하기 위하여 RAW264.7 세포주에 19종의 모자반 추출물을 처리하였으며, $\mathrm{LPS}$ 를 처리하여 NO 생성을 유도하였고, 각 모자반 추출물의 처리를 통한 $\mathrm{NO}$ 생성억제효과를 확인하였다. 실험결과(Fig. $4 \mathrm{~B})$, 비틀대모자반 $(85.44 \%)$, 외톨개모자반(84.73\%), 잔가시 모자반 $(83.42 \%)$, 큰열매모자반 $(81.20 \%)$, 그리고 꽈배기모자 반(80.13\%) 순으로 NO 생성을 $80 \%$ 이상억제하는 우수한 효 과를 보였다. Jeong 등(2014a)의 연구에서 잔가시모자반은 LPS로 염증을 유도한 대식세포의 NO 방출량을 $80 \%$ 이상 감소시켰으며, cytokine 역시 눈에 띄게 감소시키는 결과를 보였다. 또한, 기존에 잔가시모자반(Jeong 등, 2014b)과 외톨 개모자반(Kim 등, 2015b)이 아토피 피부 염증을 완화하고, 큰열매모자반이 Raw 264.7에 대한 우수한 항염증 활성을 나 타낸다고 보고하였는데(Cheon 등, 2017), 기존 보고들로 미 루어 볼 때, 모자반 추출물들이 염증 매개물질의 조절에 중요 한 역할을 하는 것으로 사료된다.

한편, 높은 항산화 활성 및 지질 축적억제 효과를 보였던 꽈배기 모자반의 경우, $70 \%$ 이상의 높은 $\mathrm{NO}$ 생성억제능을 보여 항염 효과 또한 우수함을 나타내었는데, 꽈배기모자반 이 함유한 페놀성 물질 분석과 다양한 생리활성 매커니즘에 대한 추가 연구가 요구된다.

\section{요 약}

본 연구에서는 국내산 모자반의 기능성 소재 개발 연구의 일환으로 19 종의 모자반류의 라디칼 소거능, 지질축적억제효 과 및 $\mathrm{NO}$ 생성억제효과를 평가하였다. 생리활성 평가에 사 용된 모자반 19종은 정도의 차이는 있었으나 높은 페놀 함량 에 비례하여 높은 라디칼 소거능을 나타내었으며, 지방세포 분화과정에서 생성되는 지질 축적과 대식세포에서의 $\mathrm{NO}$ 생 성을 억제하는 데 높은 효과를 나타내었다. 특히 꽈배기 모자 반의 경우 높은 페놀 함량, 항산화 활성, 지질 생성 감소 효과 및 항염증 효과를 나타내었다. 최근 모자반의 다양한 생리활 성이 보고됨에 따라 새로운 기능성 자원으로 주목받고 있어, 앞으로 기능성 식품의 자원으로서 이용할 가능성이 매우 클 것으로 기대된다.

\section{Conflict of interests}

The authors declare no potential conflict of interest.

\section{ORCID}

SoHyeon You https://orcid.org/0000-0001-9928-7379

Miran Jang https://orcid.org/0000-0001-5934-982X

Gun-Hee Kim https://orcid.org/0000-0001-8196-7149

\section{References}

Boo HO, Lee HH, Lee JW, Hwang SJ, Park SU. Different of total phenolics and flavonoids, radical scavenging activities and nitrite scavenging effects of Momordica charantia L. according to cultivars. Korean J Medicinal Crop Sci, 17, 15-20 (2009)

Cheon JM, Kim HS, Choi EO, Kwon DH, Choi YH, Kim BW, Hwang HJ. Anti-inflammatory activities of an ethanol extract of Sargassum macrocarpum in lipopolysaccharide (LPS)-stimulated RAW 264.7 macrophages. J Life Sci, 27, 1437-1444 (2017)

Cho HD, Kim DH, Kim MG, Lee YS, Seo KI. Biological activity of Oenothera biennis seed extracts. J Life Sci, 28, 1048-1055 (2018)

Cho M, Lee DJ, You S. Radical scavenging activity of ethanol extracts and solvent partitioned fractions from various red seaweeds. Ocean Polar Res, 34, 445-451 (2012) 
Cho SH, Choi YJ, Rho CW, Choi CY, Kim DS, Cho SH. Reactive oxygen species and cytotoxicity of bamboo (Phyllostachys pubescens) sap. Korean J Food Preserv, 15, 105-110 (2008)

Cho SH, Kang SE, Cho JY, Kim AR, Park SM, Hong YK, Ahn DH. The antioxidant properties of brown seaweed (Sargassum siliquastrum) extracts. J Med Food, 10, 479-485 (2007)

Choi HY, Kim GH. Inhibitory effects of Allium senescens L. methanol extracts on reactive oxygen species production and lipid accumulation during differentiation in 3T3-L1 cells. Korean J Food Sci Technol, 46, 498-504 (2014)

Choi JH, Park YH, Lee IS, Lee SP, Yu MH. Antioxidant activity and inhibitory effect of Aster scaber Thunb. extract on adipocyte differentiation in 3T3-L1 cells. Korean J Food Sci Technol, 45, 356-363 (2013)

Choi MW, Kim HR, Lee HG, Kim JI. Effect of a Sargassum serratifolium extract on neuroinflammation induced by lipopolysaccharides in mice. Korean J Fish Aquat Sci, 52, 81-86 (2019)

Choi SJ, Lee YS, Kim JK, Kim JK, Lim SS. Physiological activities of extract from edible mushrooms. J Korean Soc Food Sci Nutr, 39, 1087-1096 (2010)

Choi YJ, Park MH, Kim YS, Jung KI. Antioxidant and anti-inflammatory effects of Abies holophylla leaf extract in LPS-induced RAW 264.7 cells. J Korean Soc Food Sci Nutr, 49, 569-577 (2020)

Folin O, Denis W. On phosphotungstic-phosphomolybdic compounds as color reagents. J Biol Chem, 12, 239-243 (1912)

Jeong DH, Kang BK, Kim KBWR, Kim MJ, Ahn DH. Anti-inflammatory activity of Sargassum micracanthum water extract. J Appl Biol Chem, 57, 227-234 (2014a)

Jeong DH, Kim KBWR, Kim MJ, Kang BK, Bark SW, Park WM, Kim BR, Park HM, Im MH, Ahn DH. Anti-atopic activity of Sargassum micracanthum ethanol extracts. Korean J Microbiol Biotechnol, 42, 82-88 (2014b)

Jo YH, Park JW, Lee JM, Ahn GH, Park HR, Lee SC. Antioxidant and anticancer activities of methanol extracts prepared from different parts of Jangseong Daebong persimmon (Diospyros kaki cv. Hachiya). J Korean Soc Food Sci Nutr, 39, 500-505 (2010)

Jung KM, Kim SY, Lee SH. In vitro correlation and analysis of anti-oxidant and anti-inflammatory activities by fruit ripening of peach cultivars. Korean J Food Preserv, 24, 638-646 (2017)

Kim EJ, Choi JY, Yu MR, Kim MY, Lee SH, Lee BH. Total polyphenols, total flavonoid contents, and antioxidant activity of Korean natural and medicinal plants. Korean J Food Sci Technol, 44, 337-342 (2012)

Kim JH, Kang HM, Lee SH, Lee JY, Park LY. Antioxidant and $\alpha$-glucosidase inhibition activity of seaweed extracts. Korean J Food Preserv, 22, 290-296 (2015a)

Kim KBWR, Kang BK, Ahn NK, Choi YU, Bae NY, Park JH, Park SH, Kim MJ, Ahn DH. Inhibitory effects of Myagropsis myagroides ethanol extract on 2,4-dinitrochlorobenzene-induced atopic dermatitis-like skin lesions in mice. J Korean Soc Food Sci Nutr, 44, 1121-1127 (2015b)

Kim SJ, Lee G, Moh SH, Park J, Auh CK, Chung Y, Ryu TK, Lee TK. Phenolic contents and antioxidant activities of six edible seaweeds. J Korea Acad Industr Coop Soc, 14, 3081-3088 (2013)

Kim TH, Ko SC, Oh GW, Park HH, Lee DS, Yim MJ, Lee JM, Yoo JS, Kim CS, Choi IW, Jung WK. Studies on bioactive substances and antioxidant activities of marine algae from Jeju Island. J Mar Biosci Biotechnol, 8, 30-38 (2016)

Koh YJ, Cha DS, Choi HD, Park YK, Choi IW. Hot water extraction optimization of dandelion leaves to increase antioxidant activity. Korean J Food Sci Technol, 40, 283-289 (2008)

Kong CS, Lee JI, Kwon MS, Seo Y. Inhibitory effect of crude extracts from a brown alga Sargassum siliquanstrum on 3T3-L1 adipocyte differentiation. Ocean Polar Res, 37, 279-285 (2015)

Koo JG, Choi YS, Kwak JK. Blood-anticoagulant activity of fucoidans from sporophylls of Undaria pinnatifida, Laminaria religiosa, Hizikia fusiforme and Sargassum fulvellum in Korea. Korean J Fish Aquat Sci, 34, 515520 (2001)

Kwak CS, Lee JH. In vitro antioxidant and antiinflammatory effects of ethanol extracts from sprout of evening primrose (Oenothera laciniata) and gooseberry (Actinidia arguta). J Korean Soc Food Sci Nutr, 43, 207-215 (2014)

Kwon DH, Choi YH, Kim BW, Hwang HJ. Effects of 
ethanol extract of Sargassum horneri on adipocyte differentiation and adipogenesis in 3T3-L1 preadipocytes. J Life Sci, 29, 209-214 (2019)

Kwon YR, Youn KS. Antioxidant and physiological activities of Hijikia fusiforme by extraction methods. Korean J Food Preserv, 24, 631-637 (2017)

Lee CH, Park YN, Lee SG. Analysis and comparison of bioactive compounds and total antioxidant capabilities of Korean brown algae. Korean J Food Sci Technol, 52, 54-59 (2020)

Lee HJ, Son DJ, Kang MH, Lee BC, Hong JT. Effects of lignan compound of sesame on LPS-induced nitric oxide generation in murine macrophage RAW 264.7 cells. J Soc Cosmet Scientists Korea, 32, 173-180 (2006)

Lee SH, Jin KS, Kwon HJ, Kim BW. Anti-oxidative and anti-inflammatory activities of Carpinus pubescens Burkill extract in RAW 264.7 cells. Microbiol Biotechnol Lett, 44, 117-123 (2016)

Lee YJ, Kim JH, Oh JW, Shin GH, Lee JS, Cho JH, Park $\mathrm{JJ}$, Lim $\mathrm{JH}$, Lee $\mathrm{OH}$. Antioxidant and anti-adipogenic effects of kohlrabi and radish sprout extracts. Korean J Food Sci Technol, 46, 531-537 (2014)

Lee YJ, Yoon BR, Choi HS, Lee BY, Lee OH. Effect of Sargassum micracanthum extract on lipid accumulation and reactive oxygen species (ROS) production during differentiation of 3T3-L1 preadipocytes. Korean J Food Preserv, 19, 455-461 (2012)

Lee YM, Bae JH, Jung HY, Kim JH, Park DS. Antioxidant activity in water and methanol extracts from Korean edible wild plants. J Korean Soc Food Sci Nutr, 40, 29-36 (2011)

Oak JH, Lee IK. Taxonomy of the genus Sargassum (Fucales, Phaeophyceae) from Korea I. Subgenus Bactrophycus section Teretia. Algae, 20, 77-90 (2005)

Oh JH, Lee Y. Effects of water and ethanol extracts from four types of domestic seaweeds on cell differentiation in 3T3-L1 cell line. J East Asian Soc Diet Life, 25, 990-998 (2015)

Park JH, Bae NY, Park SH, Kim MJ, Kim KBWR, Choi JS, Ahn DH. Antioxidant effect of Sargassum coreanum root and stem extracts. KSBB J, 30, 155-160 (2015)

Park J, Lee J, Jun W. Radical scavenging and anti-obesity effects of various extracts from turmeric (Curcuma longa L.). J Korean Soc Food Sci Nutr, 42, 1908-1914 (2013) Park YH, Choi JH, Whang K, Lee SO, Yang SA, Yu MH. Inhibitory effects of lyophilized dropwort vinegar powder on adipocyte differentiation and inflammation. J Life Sci, 24, 476-484 (2014)

Ramos A, Visozo A, Piloto J, Garcia A, Rodrıguez C, Rivero R. Screening of antimutagenicity via antioxidant activity in Cuban medicinal plants. J Ethnopharmacol, 87, 241-246 (2003)

Re R, Pellegrini N, Proteggente A, Pannala A, Yang M, Rice-Evans C. Antioxidant activity applying an improved ABTS radical cation decolorization assay. Free Radic Biol Med, 26, 1231-1237 (1999)

Son HJ, Um MY, Kim I, Cho S, Han D, Lee C. In vitro screening for anti-dementia activities of seaweed extracts. J Korean Soc Food Sci Nutr, 45, 966-972 (2016)

Yeon JH, Seo HB, Oh SH, Choi WS, Kang DH, Lee HY, Jung KH. Bioethanol production from hydrolysate of seaweed Sargassum sagamianum. KSBB J, 25, 283-288 (2010)

Yoon BR, Lee YJ, Kim SG, Jang JY, Lee HK, Rhee SK, Hong HD, Choi HS, Lee BY, Lee OH. Antioxidant effect of hot water and ethanol extracts from Cheonnyuncho (Opuntia humifusa) on reactive oxygen species (ROS) production in 3T3-L1 adipocytes. Korean J Food Preserv, 19, 443-450 (2012) 